\title{
Implementation of evidence-based practices in the perineal pain management in the postpartum period
}

\author{
Implementação de práticas baseadas em evidências no manejo da dor perineal no período pós-parto \\ Implementación de prácticas basadas en evidencias para manejar el dolor perineal durante el período posparto
}

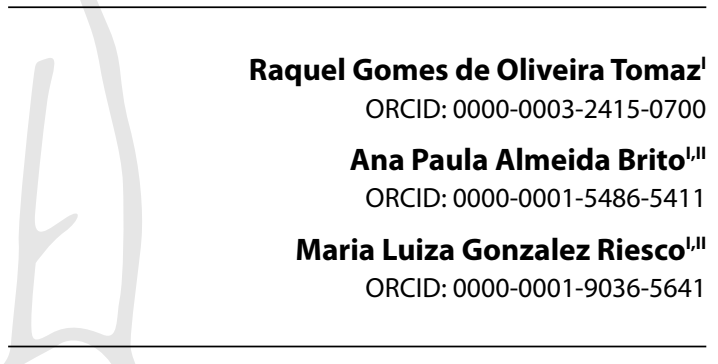

Universidade de São Paulo. São Paulo, São Paulo, Brazil. "Centro Brazileiro para o Cuidado à Saúde Baseado em Evidências: Centro de Excelência do JBI. São Paulo, São Paulo, Brazil.

How to cite this article:

Tomaz RGO, Brito APA, Riesco MLG. Implementation of evidence-based practices in the perineal pain management in the postpartum period. Rev Bras Enferm. 2022;75(2):e20210084. https://doi.org/10.1590/0034-7167-2021-0084

\section{Corresponding author:}

Raquel Gomes de Oliveira Tomaz

E-mail: got.raquel@gmail.com

EDITOR IN CHIEF: Antonio José de Almeida Filho ASSOCIATE EDITOR: Hugo Fernandes

Submission: 03-09-2021

Approval: 05-26-2021

\begin{abstract}
Objectives: To implement strategies for managing perineal pain in puerperal women admitted to a public maternity hospital in São Paulo state and to evaluate their compliance with evidence-based practices. Methods: Implementation study using the JBI model conducted with nursing professionals and puerperal women between September and December 2019. Interviews with puerperal women and medical record data were used to audit seven evidencebased criteria. The interventions adopted included a care protocol, professional training, and folder elaboration for puerperal women. Results: Prior to the intervention, deficits in audited practices and obstacles to pain management were identified, which were overcome by the strategies employed. The follow-up audit demonstrated improvements in compliance with best care practices. Conclusion: There was an increase in the criteria compliance evaluated after the implemented strategies, contributing to improving the nursing care results in the perineal pain management based on the best scientific evidence.

Descriptors: Inservice Training; Pain; Perineum; Postpartum Period; Evidence-Based Practice.
\end{abstract}

\section{RESUMO}

Objetivos: Implementar estratégias de manejo da dor perineal em puérperas internadas em uma maternidade pública do estado de São Paulo e avaliar sua conformidade com as práticas baseadas em evidências. Métodos: Estudo de implementação que utilizou o modelo do $\mathrm{JBI}$, realizado com profissionais de enfermagem e puérperas, entre setembro e dezembro de 2019. Utilizaram-se entrevistas com puérperas e dados de prontuário para auditar sete critérios baseados em evidências. As intervenções adotadas foram um protocolo de cuidados, treinamento de profissionais e elaboração de folder para puérperas. Resultados: Antes da intervenção, identificaram-se déficits nas práticas auditadas e barreiras ao manejo da dor, que foram superadas pelas estratégias empregadas. A auditoria de seguimento demonstrou melhorias no cumprimento das melhores práticas de cuidado. Conclusões: Houve aumento da conformidade dos critérios avaliados após as estratégias implementadas, contribuindo para melhora dos resultados da assistência de enfermagem no manejo da dor perineal baseada nas melhores evidências científicas.

Descritores: Capacitação em Serviço; Dor; Períneo; Período Pós-Parto; Prática Clínica Baseada em Evidências.

\section{RESUMEN}

Objetivos: Implementar estrategias para manejar el dolor perineal en puérperas en una maternidad pública de São Paulo y evaluar su conformidad con prácticas basadas en evidencias. Métodos: Estudio de implementación realizado mediante el modelo JBI con profesionales de enfermería y puérperas, entre septiembre-diciembre de 2019. Se utilizaron entrevistas con puérperas y datos de registros hospitalarios para auditar siete criterios basados en evidencias. Las intervenciones fueron: protocolo de atención; capacitación de los profesionales; preparación de una carpeta para puérperas. Resultados: Antes de la intervención, se identificaron déficits en las prácticas y barreras en el manejo del dolor, que se superaron con las estrategias empleadas. La auditoría de seguimiento trajo mejoras en el cumplimiento de las prácticas de cuidado. Conclusiones: Hubo aumento en la conformidad de los criterios evaluados tras las estrategias implementadas, lo que contribuyó a mejorar la atención de enfermería en el manejo del dolor perineal basada en evidencias científicas. Descriptores: Capacitación en Servicio; Dolor; Perineo; Periodo Posparto; Práctica Clínica Basada en la Evidencia. 


\section{INTRODUCTION}

Postpartum perineal pain is a common condition due to spontaneous or surgical trauma, such as episiotomy, which can negatively affect the puerperal period. Pain can cause reduced mobility and discomfort, interfere with the establishment of breastfeeding, newborn care development, and self-care activities, such as sleep, rest, urination, and bowel movements. It can also impact the sexual relationship and home life, causing psychological and emotional problems during the puerperium ${ }^{(1-2)}$. Therefore, proper perineal pain management is necessary, including evidence-based best practices, for women's quality care in the postpartum period.

The JBI (Joanna Briggs Institute) is an international research and development organization specializing in providing health care professionals with resources for evidence-based clinical practice. Recommendations for best practice in postpartum perineal pain management are based on evidence from systematic reviews ${ }^{(3-9)}$, evidence-based guideline ${ }^{(10)}$, randomized clinical trials $\mathbf{s}^{(11-18)}$, and expert opinions ${ }^{(19)}$. The evidence grade for these recommendations is rated $A$ - when there is a strong recommendation for a given health strategy, where the desirable effects outweigh the undesirable effects; if there is adequate quality evidence supporting its use; if there is a benefit or no impact on resource use and if the patient values, preferences, and experience have been considered - and B - when the desirable effects appear to outweigh the strategy's undesirable effects, although this is not as clear; if there is evidence to support its use, although this may not be high-quality; if there is a benefit, no impact, or minimal impact on resource use and if patient values, preferences, and experience may or may not have been taken into account ${ }^{(20)}$.

These recommendations are:

- Women should be informed about the importance of perineal hygiene, including changing pads frequently, washing their hands before and after doing so, and bathing daily to keep their perineum clean (Grade A evidence).

- Women experiencing perineal pain after should receive oral nonsteroidal anti-inflammatory drugs (NSAIDs) for pain relief unless there is a specific contraindication. Paracetamol or acetaminophen can also be considered (Grade A evidence).

- Ice compresses or cold gel may be recommended to reduce perineal pain after birth should be offered to women to improve the pain level (Grade B evidence).

- Oral and rectal analgesia have proven effective in reducing perineal pain, but rectal analgesia acceptance by some women may affect its use (Grade B evidence).

- Opioid analgesics should only be prescribed if the woman has not achieved adequate pain relief with non-opioid treatments (Grade B evidence).

Although some recommended practices were adopted, such as ice application, guidance on perineal hygiene, and painkiller administration in the maternity ward of the University Hospital of Universidade de São Paulo (HU-USP), there was no systematization and conformity for best practice implementation by the entire nursing team.
From these recommendations, this study aimed to contribute in promoting evidence-based practices related to the perineal pain management in puerperal women hospitalized at the $\mathrm{HU}$ USP, following the evidence implementation model developed by the $\mathrm{JBI}^{(20-21)}$ and thus to systematize and promote better quality care to women in the postpartum period.

\section{OBJECTIVES}

To implement strategies for managing perineal pain in puerperal women admitted to the hospital and evaluate their compliance with evidence-based practices.

\section{METHODS}

\section{Ethical Aspects}

The Research Ethics Committee of the Nursing School of Universidade de São Paulo and the Research Ethics Committee of the HU-USP approved the project, according to Resolution No. 466 of the National Health Council. Those who agreed to participate in the project signed the Informed Consent Form, where one copy remained with the project leader and the other with the research participant.

\section{Design, period and study site}

Implementation study, with reporting guided by the StaRI (Standards for Reporting Implementation Studies Statement) tool. This tool is a guideline for implementation studies, employing a variety of study designs to develop and evaluate implementation strategies, aiming to increase the adoption and sustainability of effective interventions ${ }^{(22)}$.

The study employed the nursing care clinical audit process, reaudit and feedback to implement evidence-based best practices in the perineal pain management, using the tools called Practical Application of Clinical Evidence System (PACES) and Getting Research into Practice (GRiP) and the methodology developed by JBI ${ }^{(21)}$.

The PACES online instrument is a JBI tool developed to facilitate the evidence implementation in clinical practice. This instrument lists the topics or criteria for conducting a clinical audit. These criteria, resulting from scientific evidence obtained from systematic reviews and primary studies, are established by the JBI and made available on the PACES platform. GRiP is a device used to record and analyze obstacles to implementing best practices, to discuss and define strategies to be used to overcome these obstacles, aiming to improve the audit criteria compliance level ${ }^{(21)}$.

Operationalization and systematization of best practice implementation followed the JBI precepts, which comprise three activity phases: baseline audit, implementation, and follow-up audit (or post-implementation). These phases are described below:

- First phase: selecting the implementation topic and preparing/planning for the baseline audit; establishing the implementation team; presenting the proposal to the nurse manager and the staff involved and conducting the baseline audit; 
- Second phase: analysis and discussion of the baseline audit results; identifying barriers to non-compliance with best practices; planning interventions for improvement and best practice implementation;

- Third phase: conducting the follow-up audit (or postimplementation audit); analyzing and discussing the results, comparing them with those of the baseline audit; presenting the results to the professionals involved ${ }^{(21)}$.

The study was conducted in the HU-USP maternity ward, which is located in São Paulo city, a public health and teaching institution, with secondary complexity care, containing 134 beds, of which 32 are allocated to the Rooming-in (RI) sector, where data collection occurred. The birth average number is 211 per month. The study was developed from September to December 2019.

\section{Population: inclusion and exclusion criteria}

The sample was composed of puerperal women admitted to the Rl, who had had a vaginal birth, and the nursing staff (10 nurses, 11 resident nurses, and 20 nursing technicians). We excluded puerperal mothers who were younger than 18 years old, who did not understand the language or were discharged early, as well as the nursing staff professionals who were on vacation or sick leave.

\section{Study Protocol}

The first phase was to establish the team and conduct the baseline audit. This audit seeks to determine compliance levels of current assistance with best practice recommendations. The team was coordinated by the implementation project leader, responsible for planning and defining the nursing team in the audit process, designing the tools used to implement best practices, and collecting data. The resident nurse was appointed as a leader, who was in frequent contact with the nursing team and with puerperal women's care at the time of the study. The leader was supported by a RI nurse-midwife, a JBI trainer, who also assisted with data collection. The team was also composed by an undergraduate nursing student and the RI head nurse, who also participated in data collection. Regarding the nursing team participation in the audit process, all professionals were included, to enable greater assistance systematization in the postpartum perineal pain management.

In order to establish compliance levels with best practice recommendations, this project used seven audit criteria generated by the JBI-PACES program. The resulting evidence-based best practice audit criteria are described in Chart 1.

The baseline audit occurred for 30 days, from 07/09/2019 to $07 / 10 / 2019$. An instrument was developed and interviews and chart analysis were conducted to identify compliance of current nursing care with best practice recommendations in the perineal pain management in puerperal women.

The interview with puerperal women was conducted through closed questions about postpartum perineal pain occurrence, analgesic medication administration, and orientation about perineal care by the team. The interview with nursing professionals consisted of closed questions about previous training on postpartum perineal pain management. We tried to verify records on perineal pain assessment, ice pack application, and analgesic and opiate medication administration in the medical record analysis.

Chart 1 - Audit criteria, sample, and method for measuring compliance with best practice, São Paulo, São Paulo, Brazil, 2020

\begin{tabular}{|c|c|c|}
\hline Audit Criteria & Sample & $\begin{array}{l}\text { Method used to measure } \\
\% \text { compliance with best } \\
\text { practices }\end{array}$ \\
\hline $\begin{array}{l}\text { 1. Did the nursing } \\
\text { staff receive } \\
\text { education on the } \\
\text { puerperal woman's } \\
\text { guidance for } \\
\text { perineal care? }\end{array}$ & $\begin{array}{l}\text { Nursing } \\
\text { Professionals } \\
\text { baseline audit: } \\
n=41 \\
\text { follow-up audit: } \\
n=41\end{array}$ & $\begin{array}{l}\text { Interview with staff to } \\
\text { determine their knowledge. } \\
\text { It was considered as } \\
\text { compliant if the professional } \\
\text { answers were "yes". }\end{array}$ \\
\hline $\begin{array}{l}\text { 2. Were ice packs } \\
\text { implemented for } \\
\text { perineal pain in the } \\
\text { first } 24-72 \text { hours } \\
\text { after birth? }\end{array}$ & $\begin{array}{l}\text { Puerperal } \\
\text { women } \\
\text { baseline audit: } \\
n=81 \\
\text { follow-up audit: } \\
n=88\end{array}$ & $\begin{array}{l}\text { Medical record analysis, by } \\
\text { observing records on ice } \\
\text { pack implementation. It } \\
\text { was considered compliant } \\
\text { if there was an entry in the } \\
\text { medical record. }\end{array}$ \\
\hline $\begin{array}{l}\text { 3. Was daily } \\
\text { assessment/ } \\
\text { monitoring of } \\
\text { perineal pain } \\
\text { performed after } \\
\text { birth? }\end{array}$ & $\begin{array}{l}\text { Puerperal } \\
\text { women } \\
\text { baseline audit: } \\
n=81 \\
\text { follow-up audit: } \\
n=88\end{array}$ & $\begin{array}{l}\text { Medical record analysis, } \\
\text { by observing assessment } \\
\text { records on perineal pain. It } \\
\text { was considered compliant } \\
\text { if there was an entry in the } \\
\text { medical record. }\end{array}$ \\
\hline $\begin{array}{l}\text { 4. Were oral } \\
\text { analgesics } \\
\text { prescribed for } \\
\text { pain relief offered } \\
\text { to women with } \\
\text { postpartum } \\
\text { perineal pain? }\end{array}$ & $\begin{array}{l}\text { Puerperal } \\
\text { women } \\
\text { baseline audit: } \\
n=81 \\
\text { follow-up audit: } \\
n=88\end{array}$ & $\begin{array}{l}\text { Medical record analysis, by } \\
\text { observing records on oral } \\
\text { analgesics administration. It } \\
\text { was considered compliant } \\
\text { if there was an entry in the } \\
\text { medical record. }\end{array}$ \\
\hline $\begin{array}{l}5 . \text { Did women } \\
\text { receive education } \\
\text { about postnatal } \\
\text { perineal care? }\end{array}$ & $\begin{array}{l}\text { Puerperal } \\
\text { women } \\
\text { baseline audit: } \\
n=81 \\
\text { follow-up audit: } \\
n=88\end{array}$ & $\begin{array}{l}\text { Interview with women } \\
\text { to determine if they had } \\
\text { received education about } \\
\text { postnatal perineal care } \\
\text { It was considered compliant } \\
\text { if the puerperal women } \\
\text { answers were "yes". }\end{array}$ \\
\hline $\begin{array}{l}\text { 6. Were prescribed } \\
\text { oral opioids } \\
\text { offered when oral } \\
\text { analgesics are not } \\
\text { sufficient for pain } \\
\text { relief? }\end{array}$ & $\begin{array}{l}\text { Puerperal } \\
\text { women } \\
\text { baseline audit: } \\
\mathrm{n}=81 \\
\text { follow-up audit: } \\
\mathrm{n}=88\end{array}$ & $\begin{array}{l}\text { It was considered according } \\
\text { to whether there was } \\
\text { a record in the medical } \\
\text { record. Not applicable when } \\
\text { the woman does not report } \\
\text { pain or when oral analgesics } \\
\text { are sufficient for pain relief. }\end{array}$ \\
\hline $\begin{array}{l}\text { 7. If an oral } \\
\text { opioid was being } \\
\text { considered, did } \\
\text { women and their } \\
\text { families receive } \\
\text { counseling about its } \\
\text { risks, benefits, and } \\
\text { toxicity signs? }\end{array}$ & $\begin{array}{l}\text { Puerperal } \\
\text { women } \\
\text { baseline audit: } \\
n=81 \\
\text { follow-up audit: } \\
n=88\end{array}$ & $\begin{array}{l}\text { Interview with puerperal } \\
\text { women. It was considered } \\
\text { compliant if the puerperal } \\
\text { claimed to have received } \\
\text { orientation and was not } \\
\text { applicable if an oral opiate } \\
\text { was not needed. }\end{array}$ \\
\hline
\end{tabular}

\section{Results analysis and statistics}

In phase two, the baseline audit results were presented to the project team, with whom we discussed the obstacles in implementing best practices and strategies to increase audit 
criteria compliance. The JBI-GRiP tool was used to document the obstacles found, the strategies, and the resources needed to overcome the obstacles. The obstacles we encountered, the strategies to overcome, the resources needed, and the results achieved are shown in Box 2 in the Results section.

The main interventions developed were: elaborating an institutional protocol for the postpartum perineal pain management; an educational program for the nursing staff, trainings about the best evidence-based practices, and educational folder elaboration for postpartum women, containing the main perineal care to be taken by women after childbirth.

After the best practices were implemented, the follow-up audit was conducted for 30 days, from 07/11/2019 to 07/12/2019, along the same lines as the baseline audit, using the same criteria and data collection method. Hence, the compliance results for each audited criteria were compared before and after the best practices implementation.

\section{RESULTS}

The seven audited criteria (1. Nursing staff received educational training on guiding the puerperal women to perineal care; 2 . Ice compresses were implemented within the first 24-72 hours after birth; 3. Daily assessment/monitoring of perineal pain was performed after birth; 4 . Analgesia was administered for perineal pain; 5 . Women received guidance on postnatal perineal care; 6 . Prescribed oral opioids were offered when oral analgesics were not sufficient for pain relief; 7. If an oral opioid was under consideration, women and their families received counseling on its risks, benefits and toxicity signs) were derived from a systematic literature evidence search from systematic reviews ${ }^{(3-9)}$, evidence-based guidelines ${ }^{(10)}$, randomized clinical trials ${ }^{(11-18)}$, and expert opinion ${ }^{(19)}$.

\section{Baseline Audit}

There were 92 women with vaginal birth (74 normal, 18 forceps), among who 11 were not included in the study (7 puerperal women were less than 18 years old, 2 did not understand the language, and 2 were discharged early). Therefore, 81 women were part of the data collection, and 41 nursing professionals were interviewed.

The audit compliance rates are shown in Figure 1.

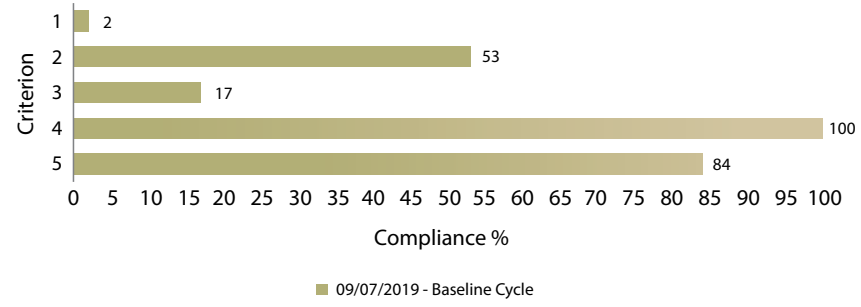

Criteria Caption:

1. The nursing staff received educational training on perineal care orientation; 2 . Ice packs were implemented in the first 24-72 hours after birth; 3. Daily perineal pain assessment/monitoring was performed after birth; 4 . Analgesia was administered for perineal pain; 5 . Women received guidance on postnatal perineal care.

Figure 1 - Compliance with best practices for criteria in percentage-based auditing (\%), São Paulo, São Paulo, Brazil, 2020
Regarding criteria 1"Has the nursing staff received educational training on perineal care orientation for puerperal women?", out of the 41 professionals interviewed, 40 (98\%) reported having had no training on the perineal pain management based on scientific evidence. In contrast, one professional (2\%) had received training on perineal care in another institution.

Among 81 postpartum vaginal women, 38 (47\%) reported perineal pain. Out of those, 20 used ice packs regularly on the perineum between 24-72 hours after birth, accounting for 53\% compliance with criteria 2 "Were ice packs implemented for perineal pain in the first 24-72 hours after birth?".

Criteria 6"Were oral opioids offered prescribed when oral analgesics were not sufficient for pain relief?" and 7"If an oral opioid was being considered, did women and their families receive counseling on its risks, benefits and toxicity signs?" were not evaluated, as opioid analgesia did not need to be administered, since non-opioid analgesics and NSAIDs were sufficient for perineal pain relief.

Regarding perineal trauma, $21 \%$ had no laceration, $25 \%$ had a first-degree laceration, $23 \%$ had a second-degree laceration, $1 \%$ had a third-degree laceration and episiotomy was performed in $30 \%$.

\section{Obstacles and strategies according to Joanna Briggs In- stitute - Getting Research into Practice}

The obstacles we encountered, the strategies to overcome, the resources needed, and the results achieved are shown in Chart 2.

Regarding the lack of an institutional protocol for postpartum perineal pain management, an evidence-based nursing protocol entitled "Postpartum perineal pain management" was developed. It aimed to implement best practices in the perineal pain management in postpartum vaginal women and standardize the cold compresses use, evaluation, and perineal pain recording.

In order to overcome the nursing professionals'lack of knowledge about the best evidence in perineal pain management, a training educational program on best practices was created. A flowchart was developed to manage postpartum perineal pain and discussed with nursing professionals during the educational program. The training was done by developing and exhibiting of an educational video, dialogical exposition about the flowchart created for the perineal pain management, and development of an educational game, in puzzle format, to summarize the best practices. Each employee participated in a mobile educational puzzle game, compiling a summary of best practices in perineal pain management. The educational training lasted an average of 10 minutes, covered employees on all shifts during working hours, and covered 100\% of the staff, in October 2019.

\section{Follow-up Audit}

The follow-up audit was conducted from 07/11/19 to 07/12/19 and the data collection was performed by the implementation team, by utilizing the same collection tool and auditing the same criteria in the same way as performed during the baseline audit.

In this period, there were 100 women with vaginal birth (88 normal, 12 forceps), among which 12 were not included in the study (10 puerperal were less than 18 years old and 2 were discharged early). Thus, 88 women were included in the data collection, and 41 nursing professionals were interviewed. 
Chart 2 - Joanna Briggs Institute - Getting Research into Practice Tool Execution Matrix, São Paulo, São Paulo, Brazil, 2020

\begin{tabular}{|l|l|l|l|}
\hline Obstacles Encountered & Strategies & Resources & Results \\
\hline $\begin{array}{l}\text { Non-existence of } \\
\text { institutional protocol }\end{array}$ & $\begin{array}{l}\text { Elaboration of a protocol, together with the teaching } \\
\text { and quality service, on the postpartum perineal pain } \\
\text { management. }\end{array}$ & $\begin{array}{l}\text { Computer with Internet; } \\
\text { books on NANDA-I, NOC, } \\
\text { and NIC }\end{array}$ & $\begin{array}{l}\text { The protocol has been } \\
\text { implemented and is available } \\
\text { on the hospital's intranet. }\end{array}$ \\
\hline $\begin{array}{l}\text { Nursing professionals' lack } \\
\text { of knowledge }\end{array}$ & $\begin{array}{l}\text { An educational program, in the form of training, on } \\
\text { evidence-based best practices. }\end{array}$ & $\begin{array}{l}\text { Computer with Internet; } \\
\text { meeting room }\end{array}$ & $\begin{array}{l}100 \% \text { of the nursing staff } \\
\text { trained. }\end{array}$ \\
\hline $\begin{array}{l}\text { No registry on perineal } \\
\text { pain assessment and the } \\
\text { application of ice packs }\end{array}$ & $\begin{array}{l}\text { Reinforcement, through educational video. } \\
\text { Elaboration and fixation of the flowchart for registry } \\
\text { on perineal pain assessment in the puerperal women's } \\
\text { medical chart. }\end{array}$ & $\begin{array}{l}\text { Computer with Internet; } \\
\text { printer with black ink and } \\
\text { bond paper }\end{array}$ & $\begin{array}{l}\text { Flowchart elaboration and } \\
100 \% \text { of the nursing team } \\
\text { trained. }\end{array}$ \\
\hline $\begin{array}{l}\text { Puerperal woman's lack of } \\
\text { knowledge about perineal } \\
\text { care }\end{array}$ & $\begin{array}{l}\text { Elaboration and fixation in educational folder wards, } \\
\text { containing the main orientations related to perineal } \\
\text { care. }\end{array}$ & $\begin{array}{l}\text { Computer with Internet; } \\
\text { printer with color ink and } \\
\text { bond paper }\end{array}$ & $\begin{array}{l}\text { Educational folders were } \\
\text { fixed in 100\% of the wards, } \\
\text { in a place visible to all } \\
\text { puerperal women. }\end{array}$ \\
\hline
\end{tabular}

\section{Audit compliance rates are shown in Figure 2.}

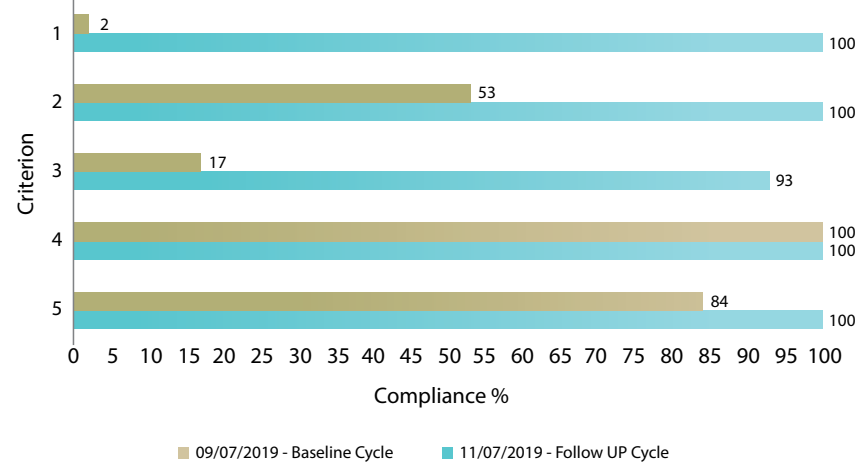

Criteria Caption:

1. The nursing staff received educational training on perineal care orientation; 2 . Ice packs were implemented in the first 24-72 hours after birth; 3. Daily perineal pain assessment/monitoring was performed after birth; 4 . Analgesia was administered for perineal pain; 5 . Women received guidance on postnatal perineal care.

Figure 2 - Compliance with best practices for criteria in follow-up audit compared to baseline audit, in percent (\%), São Paulo, São Paulo, Brazil, 2020

Regarding criteria 1 "Did the nursing staff receive educational training on guiding the puerperal women to perineal care?", all 41 nursing staff members were trained, increasing compliance by $98 \%$. Out of 88 postpartum vaginally delivered puerperal women, 38 (43\%) reported perineal pain. Among those, all used ice compresses regularly on the perineum between $24-72$ hours after birth, increasing compliance with criteria 2 "Were ice compresses implemented for perineal pain in the first $24-72$ hours after birth?" by $47 \%$.

Regarding criteria 5 "Did women receive guidance on postnatal perineal care?", all puerperal women reported receiving staff guidance on postpartum perineal care, increasing the level of compliance by $16 \%$. Criteria 6 "Were prescribed oral opioids offered when oral analgesics were not sufficient for pain relief?" and 7"If an oral opioid was considered, did women and their families receive guidance on its risks, benefits and toxicity signs?" were not assessed, as opioid analgesia did not need to be administered.

Regarding perineal trauma, 35\% had no laceration, $25 \%$ had first-degree laceration, $15 \%$ had second-degree laceration, there was no third-degree laceration, and in $25 \%$ an episiotomy was performed.

\section{DISCUSSION}

Similar work was done in an obstetric and gynecological hospital in China and showed similar results of significant improvement in all audited criteria ${ }^{(23)}$. As in this project, there was increased compliance for the criteria regarding staff training, cold compresses usage, analgesic administration, daily pain assessment, and women's orientation on perineal care.

Systematic review studies, including randomized clinical trials, pointed to evidence supporting effectiveness for local cooling treatments (ice or cold gel application for 10-20 minutes) to manage perineal pain. When applied to the perineum 24 to 72 hours after birth, they are effective in relieving pain compared to no treatment or hot bath treatment ${ }^{(11)}$.

Evidence indicates that paracetamol's oral administration is effective in relieving mild pain and NSAID suppositories use decreases perineal pain in the first 24 hours $^{(4,6)}$. Therefore, if local application of cold packs and paracetamol are not effective in relieving pain, oral or rectal NSAID medication should be considered $^{(7,10)}$.

The American College of Obstetricians and Gynecologists recommends a stepwise multimodal approach using non-opioid analgesia (acetaminophen or NSAIDs) as first-line therapy for postpartum perineal pain, with oral opioids reserved only for pain that cannot be adequately managed with non-opioid medications. The duration of opioid usage should be limited to the shortest possible course for acute pain management. If opioids are needed for postpartum pain management, the risks and benefits of the medication, including education about toxicity signs in the newborn, should be discussed with the family ${ }^{(19)}$. In this study, opioids were not necessary, this may be due to perineal trauma grades being mostly first and second grade.

According to guidelines and evidence review, women should be oriented about perineal hygiene, frequent pads exchange, and hand hygiene. Nurses' work is essential in implementing evidence-based practices through educational activities, actions to improve treatment adherence, and care and discharge plans based on patients' needs ${ }^{(24)}$.

The health care provider should perform a perineal assessment at each postpartum contact, investigating perineal pain 
experience, discomfort or burning, odor, dyspareunia, infection signs and symptoms, inadequate repair, or non-healing ${ }^{(4)}$.

The only criterion that did not reach $100 \%$ in this study was criterion 3, daily evaluation/monitoring of perineal pain is performed after birth, demonstrating the need for nursing to record, in a more detailed and systematized way, their performance. A study that sought to identify the meaning that nursing technicians attribute to the good practices applied to the parturient woman in the birth center recommends identifying the sufficient number of technicians for adequate record-keeping so that there is a nursing performance visualization and evidence-based care quality ${ }^{(25)}$.

\section{Study limitations}

The study's main limitation was the lack of records on the daily perineal pain assessment and the care provided, possibly due to issues related to human resources and time management.

\section{Contributions to the nursing field}

This study contributes to nursing care improvement by applying an international method for best evidence implementation and demonstrates the systematization viability of a protocol for postpartum perineal pain management.

\section{CONCLUSION}

After the management strategies for postpartum perineal pain were implemented, there was an improvement in all audited criteria concerning best practices based on scientific evidence.

Nevertheless, it should be kept in mind that a process to change practices takes time to be established and that in-service education should be permanent.

This project was the beginning of a process to change practices and reflections regarding perineal postpartum pain management. It also enabled implementing new strategies, including the nursing staff training and institutional protocol development based on evidence, aiming to improve the nursing care quality and bring benefits in the puerperal period for women admitted to the maternity hospital.

Cyclic follow-up audits will be required to assess compliance and continue to address obstacles to best practice. This followup will enable future improvements in the nursing care quality, continuously improving the perineal pain management and the sustainability of this project.

\section{REFERENCES}

1. Francisco AA, Oliveira SMJV, Santos JOS, Silva FMB. Evaluation and treatment of perineal pain in vaginal postpartum. Acta Paul Enferm. 2011;24(1):94-100. https://doi.org/10.1590/S0103-21002011000100014

2. He S, Jiang H, Qian X, Ganer P. Women's experience of episiotomy: a qualitative study from China. BMJ Open 2020;10(7):e033354. https:// doi.org/10.1136/bmjopen-2019-033354

3. Hedayati H, Parsons J, Crowther CA. Topically applied anaesthetics for treating perineal pain after childbirth. Cochrane Database Syst Rev. 2005;2:CD004223. https://doi.org/10.1590/S0103-21002011000100014

4. Hedayati $\mathrm{H}$, Parsons J, Crowther CA. Rectal analgesia for pain from perineal trauma following childbirth. Cochrane Database Syst Rev. 2003;3:CD003931. https://doi.org/10.1002/14651858.CD003931

5. Molakatalla S, Shepherd E, Grivell RM. Aspirin (single dose) for perineal pain in the early postpartum period. Cochrane Database Syst Rev. 2017;2:CD012129. https://doi.org/10.1002/14651858.CD012129.pub2

6. Chou D, Abalos E, Gyte GML, Gulmezoglu AM. Paracetamol/acetaminophen (single administration) for perineal pain in the early postpartum period. Cochrane Database Syst Rev. 2013;1:CD008407. https://doi.org/10.1002/14651858.CD008407.pub2

7. Wuytack F, Smith V, Cleary BJ. Oral non-steroidal anti-inflammatory drugs (single dose) for perineal pain in the early postpartum period. Cochrane Database Syst Rev. 2021;1(1):CD011352. https://doi.org/10.1002/14651858.CD011352.pub3

8. Beckmann MM, Stock OM. Antenatal perineal massage for reducing perineal trauma. Cochrane Database Syst Rev. $2013 ;(4): C D 005123$. https://doi.org/10.1002/14651858.CD005123.pub3

9. Kettle C, Tohill S. Perineal care. BMJ Clin Evid [Internet]. 2008[cited 2021 Feb 22];2008:1401. Available from: https://www.ncbi.nlm.nih.gov/ pmc/articles/PMC2907946/pdf/2008-1401.pdf

10. Demott K, Bick D, Norman R, Ritchie G, Turnbull N, Adams C, et al. Clinical guidelines and evidence review for postnatal care: routine postnatal care of recently delivered women and their babies. [Internet]. London: NICE. 2006[cited 2021 Feb 22]. Available from: https:// www.nice.org.uk/guidance/cg37/evidence/full-guideline-485782237

11. Francisco AA, Oliveira SMJV, Steen M, Nobre MRC, Souza EV. Ice pack induced perineal analgesia after spontaneous vaginal birth: randomized controlled trial. Women Birth. 2018;31(5):e334-40. https://doi.org/10.1016/j.wombi.2017.12.011

12. Morais Í, Lemos A, Katz L, Melo LFR, Maciel MM, Amorim MMR. Perineal pain management with cryotherapy after vaginal delivery: a randomized clinical trial. Rev Bras Ginecol Obstet. 2016;38(7):325-32. https://doi.org/10.1055/s-0036-1584941

13. Senol D, Aslan E. The effects of cold application to the perineum on pain relief after vaginal birth. Asian Nurs Res (Korean Soc Nurs Sci). 2017;11:276-82. https://doi.org/10.1016/j.anr.2017.11.001 
14. Manfre M, Adams D, Callahan G, Gould P, Lang S, McCubbins H, et al. Hydrocortisone cream to reduce perineal pain after vaginal birth: a randomized controlled trial. MCN Am J Matern Child Nurs. 2015;40(5):306-12. https://doi.org/10.1097/NMC.0000000000000165

15. Santos JO, Oliveira SMJV, Nobre MRC, Aranha ACC, Alvarenga MB. A randomised clinical trial of the effect of low-level laser therapy for perineal pain and healing after episiotomy: a pilot study. Midwifery. 2012;28(5):e653-9. https://doi.org/10.1016/j.midw.2011.07.009

16. Santos JO, Oliveira SMJV, Silva FMB, Nobre MRC, Osava RH, Riesco MLG. Low-level laser therapy for pain relief after episiotomy: a double blind randomised clinical trial. J Clin Nurs. 2012;21(23-24):3513-22. https://doi.org/10.1111/j.1365-2702.2011.04019.x

17. Alvarenga MB, Oliveira SMJV, Francisco AA, Silva FMB, Sousa M, Nobre MR. Effect of low-level laser therapy on pain and perineal healing after episiotomy: a triple-blind randomized controlled trial. Lasers Surg Med. 2017;49(2):181-8. https://doi.org/10.1002/lsm.22559

18. Akbarzade M, Ghaemmaghami M, Yazdanpanahi Z, Zare N, Mohagheghzadeh A, Azizi A. Comparison of the effect of dry cupping therapy and acupressure at BL23 point on intensity of postpartum perineal pain based on the short form McGill Pain Questionnaire. J Reprod Infertil [Internet]. 2016[cited 2021 Feb 22];17(1):39-46. Available from: https://www.ncbi.nlm.nih.gov/pmc/articles/PMC4769854/pdf/JRI-17-39.pdf

19. Committee on Obstetric Practice. ACOG Committee Opinion No. 742: postpartum pain management. Obstet Gynecol. 2018;132(1):e35-43. https://doi.org/10.1097/AOG.0000000000002683.

20. The Joanna Briggs Institute. The new JBI grades of recommendations [Internet]. [Adelaide]: University of Adelaide; 2013 [cited 2021 Fev 22]. Available from https://joannabriggs.org/sites/default/files/2019-05/JBI-grades-of-recommendation_2014.pdf

21. Porritt K, McArthur A, Lockwood C, Munn Z, editors. JBI handbook for evidence implementation. [Adelaide]: JBI; 2020. https://doi. org/10.46658/JBIMEI-20-01

22. Pinnock H, Barwick M, Carpenter CR, Eldridge S, Grandes G, Griffiths CJ, et al. Standards for reporting implementation studies (StaRI) statement. BMJ. 2017;356:i6795. https://doi.org/10.1136/bmj.i6795

23. Zhang Y, Huang L, Ding Y, Shi Y, Chen J, McArthur A. Management of perineal pain among postpartum women in an obstetric and gynecological hospital in China: a best practice implementation project. JBI Database System Rev Implement Rep. 2017;15(1):165-77. https://doi.org/10.11124/JBISRIR-2016-003232

24. Costa MFBNA, Sichieri K, Poveda VB, Baptista CMC, Aguado PC. Transitional care from hospital to home for older people: implementation of best practices. Rev Bras Enferm. 2020;73(Suppl 3):e20200187. https://doi.org/10.1590/0034-7167-2020-0187

25. Vieira BC, Backes MTS, Dalla Costa L, Fernandes VMB, Dias HHZR, Backes DS. Applying best practices to pregnant women in the obstetric center. Rev Bras Enferm. 2019;72(Suppl 3):199-6. https://doi.org/10.1590/0034-7167-2018-0422 